\title{
Going Beyond Overlooked Populations in Lebanese Historiography: The Armenian Case
}

\author{
Tsolin Nalbantian*
}

Leiden University

\section{Abstract}

Scholarship on the historiography of Lebanon consistently calls attention to ethnic and religious communities that have been conveniently "left out" of Lebanese history to perpetuate either a mostly Maronite imagination of Lebanon that traces its roots to Phoenician (and therefore non-Arab and non-Muslim origins) or to a larger pan-Arab narrative. Nevertheless, recent attempts to write a modified - and more inclusive - history of Lebanon continue to disregard Armenian inhabitants in the country. By exploring the Lebanese Armenian press coverage of the 1946 Repatriation Movement (a worldwide undertaking to gather all members of the Armenian Diaspora and relocate them in the Soviet Republic of Armenia), I aim to show additional articulations of citizenship, homeland, and belonging in Lebanon in the first years of its independence. Repatriation and its coverage present us with untapped resources that complicate both traditional and corrective narratives of the history of Lebanon. The exploration of these understandings allows for scholarship to go beyond the traditional constraints of viewing Lebanon as an amalgamation of sectarian divisions that need to be covered in some form to create a dominant national narrative. In addition, these findings avoid the temptation to create a more inclusive national history of Lebanon, as they present scholars with ambiguous and changing notions of who is Lebanese.

\section{Abnormal and a Propensity for Violence}

With a few notable exceptions, scholarship on Lebanese history tends to cast Lebanon as an "abnormal" nation-state, as an unnatural entity. ${ }^{1}$ In a quest to show the dysfunctional "nature" of Lebanon, many histories view Lebanon from within three prisms: war, sect, and nationalism. ${ }^{2}$ These approaches become entry-points into understanding the current schisms in Lebanese society. In attempting to provide a genealogy of civil disturbances however, historians designate conflict as an innate characteristic of Lebanon, and its presence justifies both their approach and subsequent scholarship. ${ }^{3}$

This constraint also shapes the approach of the works, as distinct historical actors and events become compressed into a sequence of conflict between communities. And while episodes of violence do indicate additional prisms that can be utilized to view Lebanon's history, such as nation, nationalism, and identification, there is an inevitable restriction in their scope. Understanding Lebanon through this parameter prevents the inclusion of histories that use additional and less common historical sources. The incorporation of these sources circumvents the narrative of aggression, challenging the reading of Lebanon as an abnormal nation-state. I argue that it is because historians of Lebanon focus on its abnormality and connect this to its propensity for violence that Armenians are seldom, if ever, represented in histories of Lebanon. When mentioned, Armenians are thereafter immediately passed over in favor of other communities that better illustrate Lebanon's abnormality. 
In critiquing the positioning of Lebanese historiography, I do not argue for or against the "naturalness" or "unnaturalness" of Lebanon or of any other nation-state. My departure from the extant scholarship entails a refutation of the notion that there exists such a "natural" nation-state to which Lebanon can be contrasted and shown to be exceptional. Abnormality explains the presence of violence and vice versa, thus simultaneously excusing and ensuring the exclusion of Armenians, as they do not reinforce either frame. Lack of evidence, rather than historical material, formulates many historians' questions.

\section{Newcomers}

Because Armenians have not been categorized as active players in the construction (or destruction) of Lebanon, they are not included in its histories. When mentioned, Armenians consistently are described as hailing from another location and experience, as "originally" refugees from the Ottoman Empire. This other origin allots Armenians in Lebanon to a different national space, and therefore, another history. The maintenance of Armenians as a non-engaged presence in Lebanon begins from their treatment as newcomers who owe their entry to French colonial practices. ${ }^{4}$

While Lebanon's sectarian system constructed Armenians into a religious and sectarian community (like other inhabitants of Lebanon), historians fail to consider whether Armenian inhabitants played a role in the construction and maintenance of Lebanese national identity and in the making of modern Lebanon. This is a marked difference from recent studies that I will profile later in this study that attempt to insert minority stories, such as the role of the Shi'i or the Druze, into the larger narrative of Lebanon. These newer histories, which challenge long privileged Maronite or Sunni Arab positionings of power in Lebanon, delve into the origins of the Shi'i and Druze communities to historicize their construction as Lebanese political identities and to locate them specifically as part of Lebanon.

\section{A Redrawing of the National?}

It is important to clarify that I am neither advocating for a mere "inclusion" of the Armenian community within Lebanese history, nor for matching attention for Armenian inhabitants as allotted to others. This indeed may be the first step that arises in such a proposal, but I argue against the need for a more "complete" history. I contend that the 1946-1949 Armenian repatriation movement, which was an organized attempt to move the worldwide population of Armenians to Soviet Armenia, informs the formation of Lebanese history. This reexamination contributes to scholarship of marginals in society, rather than promoting an Armenian nationalist "correction" of Lebanese history.

Yet, the question remains, what might be gained by examining Armenian relationships, networks, and actions - both internal to the community and connecting the Armenian to non-Armenian communities - as part of Lebanon's history?

I address this question in two ways. First, I begin by illustrating how Armenian (non) involvement is forwarded by historiographers of Armenians and of Lebanon (in English, Arabic, and Armenian), and I analyze the similar representations these historiographies construct in turn. Second, I re-investigate the summer months of 1946 integrating unnoticed events and actors in order to demonstrate how the inclusion of scholarship on Armenians in Lebanon can deepen our understandings of Lebanon, Armenians, and marginality. By looking at the voluntary population transfer of Armenians from Lebanon during 1946-1949, we discover flexibility in identification, ideas of belonging, 
and locations of homelands. ${ }^{5}$ In addition, we contribute to the genealogy of such contemporary categorizations as the nation-state and citizenship while examining additional understandings of the relationship between the loci of the nation and the nation-state.

\section{Qualifying Historiography}

1946 is a pivotal time in Lebanese political and social history for four reasons. First, it is the year that the last French mandatory forces leave Lebanon, paving the way for Lebanese independence. Second, following the French departure, the sectarian political categorizations they introduced became codified by the independent Lebanese state. Third, 1946 also marks the year when the country's inhabitants were made into Lebanese citizens of the Republic of Lebanon, superseding their status as citizens of a French Mandate. The fourth and final reason why I begin from 1946 is because this was the year of the first Armenian "repatriation" caravan that sailed from Qarantina to the USSR, bringing with it 2000 freshly minted Soviet citizens, or ex-Lebanese ones.

\section{Armenians in Lebanon within Lebanese Historiography}

By looking at a sample of Lebanese histories in English and Arabic, I show how histories of Lebanon have represented the (non)involvement of Armenians. In their project to construct Lebanon as a nation-state "destined" to fail, these works consider only the inhabitants of Lebanon who have either directly participated in the creation or attempted destruction of the state.

A House of Many Mansions: The History of Lebanon Reconsidered by Kamal Salibi and $A$ History of Modern Lebanon by Fawaz Traboulsi are two books widely cited as benchmarks of contemporary histories of Lebanon. ${ }^{6}$

Salibi intermittently mentioned Armenians five times in his work. ${ }^{7}$ None of these offered any substantial discussion of Armenians, suggesting they did not comprise of one of its "many mansions" nor did they play a remarkable role within the "house" of Lebanon. Salibi siphoned the Druze, Sunni, Shi'i, Maronite, Greek Orthodox and Greek Catholic inhabitants of Lebanon through two religious categories: Christian and Muslim. Most notably, he did not include Armenians, although most would self-identify and externally be identified as Christian. After all, Armenians were granted citizenship in 1924 by the French to bolster the Christian populace. This distinction, along with the disclaimer that Armenians did not share Arabic as a "common language" or "an Arab way of life," separated Armenian from the [other] Lebanese, and created a hierarchy of belonging. 8

While Salibi acknowledged the presence of Armenians but did not incorporate them into his history of Lebanon, Fawaz Traboulsi ignored the Armenians completely. ${ }^{9}$ There was not a single mention of Armenians in A History of Modern Lebanon, despite Traboulsi's assertion that his work filled a lacuna in the historiography of Lebanon. He wrote in the preface: "An updated history of modern Lebanon is long overdue as the last such attempt dates from the mid-1960s" and added, "while much has happened since a lot of new historical material has been uncovered and researched." ${ }^{10}$ Apparently none of the new material merited any reference to Armenians. This, even though the departure of Armenians in 1946 affected Lebanon's demography and changed the composition of Lebanon's towns and cities.

Like their English counterparts, Arabic histories of Lebanon either maintain a universal Armenian experience in Lebanon or ignore the population completely. ${ }^{11}$ Maronite histories emphasize the distinctive Phoenician origins of the country while 
ignoring the Islamic period and do not go further than mentioning the Armenians. ${ }^{12}$ Likewise, many authors with Pan-Arab affinities, such as Amin Abu Izz al-Din and Suleyman Taqi al-Din, emphasize the "Arab" texture of Lebanon, homogenizing distinct narratives. ${ }^{13}$ This approach necessarily classifies Armenians as non-Lebanese and justifies the author's subsequent circumvention. ${ }^{14}$ Recent critical histories (written in English, but analyzing Arabic and French sources) that examine how Maronite history writing aids in the construction of Maronite nationalist ideology in Lebanon, still fail to account for any Armenian involvement in potentially enforcing or challenging such imaginations. ${ }^{15}$

Tamara Chalabi, Yusri Hazran, and Max Weiss have produced works that diversify traditional representations of Lebanese history. ${ }^{16}$ Their works encompass the experiences of the Druze and the Shi'i populations of Jabal 'Amil, providing rich insight into processes of the codification of identity through the study of court records and the Arabic press. However, one key connection runs through both earlier and more recent traditional and contemporary emendations: all accounts concur that the Shi'i and the Druze populations were part of the larger composition of Lebanon. Though earlier histories tended to overlook the significance of the cultural records of the Shi'i and the Druze, they never questioned their belonging as Lebanese, or their participation in the history of Lebanon. ${ }^{17}$

Temporal notions of belonging and the consistent posturing of the origins of the Armenian community in Lebanon outside of Lebanon expose a defense of nation-state nationalism. Crudely put, recent histories of the Shi'i and the Druze claim these populations should be included within Lebanese historiography because they are Lebanese. What of communities who are more recently connected to the geographic boundaries of the country or who may not wish to be considered Lebanese? Are they simply (and justifiably) left out? This modification continues to ignore its Armenian inhabitants and their role in the construction of Lebanon's development. ${ }^{18}$ The Armenian absence in Lebanese histories prevents us from fully engaging how concepts and constructions of citizenship and identification were understood in this very formative period in Lebanese history.

\section{Armenians in Lebanon within Armenian Historiography ${ }^{19}$}

Since Salibi's referenced Armenians a handful of times, and Traboulsi did not mention them once, perhaps Armenians in Lebanon were located in another history, and not a Lebanese one. If histories were organized on the basis of national grand narratives, then Armenians in Lebanon should surely be mentioned in the first comprehensive history of the Armenians, The Armenian People from Ancient to Modern Times, edited by Richard G. Hovannisian. And yet, even though for Hovannisian "the history of the Armenian people is long, complex, and in many ways epic and heroic,"20 Armenians in Lebanon are only mentioned as refugees following the Armenian massacres in World War I and who desired to return to a historic homeland. In their quest to write an epic history of the Armenians, Hovannisian and the contributors accordingly did not consider whether and how Armenians played a role in the formation of the history of Lebanon.

A more recent contribution to Armenian historiography is Razmik Panossian's The Armenians: From Kings and Priests to Merchants and Commissars, an examination of how "Armenianness" was shaped by structural variables over time. While not a historian, Panossian's tracking of Armenianness materializes as an encompassing history of the Armenian nation. ${ }^{2}$ Similar to Hovannisian's volumes, The Armenians spans from "The Beginning of Time" through to the independence of Soviet Armenia and its transition into an independent republic. ${ }^{22}$ While Panossian does mention the Armenians in 
Lebanon specifically, he described all Armenians - regardless of their different experiences and locations - as part of a larger Armenian "diasporic nation," explaining that "Armenianness" is "the most important category...created or reinforced in the diaspora, superseding the differences within and between the communities." ${ }^{23}$ Panossian does not question the efficacy of "Armenianness" as an identification, and like the other authors, fails to examine if Armenian inhabitants in Lebanon construct additional histories, outside of the grand Armenian narrative. These narratives, which positioned Armenians as members of a larger Armenian diaspora, concurrently endorsed the Soviet Union's interpretation of Armenian identification and belonging developed during the repatriation movement of 1946-1949.

\section{The Additional Story}

The 1946-1949 Soviet-engineered repatriation drive, (known as Nerkakht in Armenian) was an organized attempt to "collect" all the Armenians located throughout the world and "return" them to the "homeland" of the Soviet Republic of Armenia. Through the official simultaneous radio broadcast on November 21, 1945 in Moscow, Yerevan, London, Paris, and Beirut, both Soviet authorities and Armenians who supported the movement designated the Soviet Republic of Armenia, one of the 15 republics of the Soviet Union, as the homeland. ${ }^{24}$ The popularity of the repatriation movement makes the phenomenon a particularly salient site for exploring the manufacturing processes of a homeland. ${ }^{25}$ In addition, the success of repatriation contributes to our command of the understandings of both citizenship and identification during this time.

Although this movement was celebrated in the Armenian (and Arabic) press in Lebanon as both a homecoming and a reunification of the Armenian nation, it was also a complex interplay of power by multiple state apparatuses - namely here the Lebanese and the Soviet - that became intimately involved with this seeming Armenian project of return. ${ }^{26}$ It is this state involvement that offers additional understandings of how the Lebanese state articulated authority in the early years of the independent republic. The Lebanese state regulated the reduction of its populace and accordingly defined a section of its membership - those Armenians who wished to "repatriate" - as expendable. Though the Armenian act of "repatriation," the Lebanese state redefining the contours of its national membership. At the same time, as it reconfigured its own members, the Lebanese state was also instrumental in constructing Soviet Armenian citizens.

In addition to exposing state power within what is traditionally seen as an Armenian diasporic project, my aim is to likewise examine the adaptability of the identification of Armenians in Lebanon during this time. The analysis of the variability in Armenian national identification challenges conventional classifications of Armenians as a Diaspora and therefore not involved in the fashioning of Lebanese history. In fact, the examination of the repatriation process reveals the manufacturing process entailed with making Armenian Lebanese citizens first into Diasporic Armenians and then into Soviet ones by various actors, including the Lebanese government.

The first caravan (as it was referred to in the press) sailed from the port of Qarantina in Beirut on June 23, carrying over 1500 Armenians. All in all, more than 100,000 heeded the call to "go home." In Syria and Lebanon alone, over 30,000 Armenians sailed from the port of Qarantina in Beirut. This, even though none of these passengers were "from" the geographic boundary of Soviet Armenia. ${ }^{29}$ While homelands seldom correspond to the geographic location of a person's origins, and rather, manifest where one imagines themselves to belong, this 1946 Armenian homeland was constructed by 
Soviet officials and abetted by Syrian and Lebanese governmental ones. It was then adopted by the Armenians of Lebanon.

While the repatriation announcement ${ }^{28}$ stated that Diasporic Armenians had supported the project (and in fact it would be those Armenians who "realized" the homeland by "returning"), it was the Soviet state that sanctioned, organized, and "produced" the movement. Up until that point, the public dialog within the Armenian press in Lebanon did not include the discourse of physically "returning home." There were discussions in the press calling for the creation of an Armenia in the geographic lands of Anatolia (present day Turkey), but again, the concept of "returning," and then to Soviet Armenia was completely innovative. Once the Soviet government created the homeland, it was then advertised as the fulfillment of the Armenian national project and celebrated within the Lebanese (Armenian and Arabic) printed press. The actions of the Soviet state encouraged Armenians to shift their identification to the USSR, connecting their national struggle to the Soviet state. It is this shift that I consider a reinforcement of Soviet state power and contestation to Lebanese state power. In the change from being part of one state to becoming part of another, Armenians in Lebanon demonstrate their agency in responding to both states' powers. By examining how Armenians engaged with both the Lebanese and Soviet governments, rather than assuming they were foreign or irrelevant, we can investigate how their actions facilitated those of the Lebanese state, which accordingly redefined the membership of its population.

The political channels at work to pull off this project entailed the cooperation on a state level of various political authorities at the port of departure, arrival, and at sea, as these ships made their way to the homeland. In Lebanon, not only did the Lebanese government facilitate the arrival of the Soviet boat and its docking within its borders, but it also processed the de-naturalization of the repatriates' Lebanese citizenship. ${ }^{29}$ The Armenian repatriates had to be made into Soviet citizens in order for them to "return home." In affirming the Soviet construction of an Armenian homeland, the Lebanese state positioned members of its own state as belonging to the USSR. The Lebanese state assisted in the loss of thousands of its citizens, while engineering the growth of the Soviet Union.

The act of relinquishing Lebanese citizenship simultaneously legitimized the authority of that nation-state. Armenians recognized Lebanese state authority in seeking to leave Lebanon. In addition, the Lebanese government consolidated its power over the remaining population. And at the same time, by consenting to Soviet citizenship, both the repatriates and the Lebanese government recognized, reinforced, and expanded the authority of the Soviet state. But that's not all that's happening: The desire and the action of changing citizenship challenge the authority of a given nation-state. In other words, the act of becoming another nation-state's citizen subverts the authority of citizenship, a classification employed by state power to categorize its inhabitants. The ease and immediacy with which Armenians should switch citizenship show how state categorizations were not fixed. Moreover, the state allowed Armenians to renounce their citizenship and take another - even when this functioned at its own expense.

Without any real debate, Lebanese newspapers produced competing images of the Armenian homeland, even if the papers did not question the locus of the Armenian homeland as constructed by the Soviet and Lebanese states and maintained by the repatriates. ${ }^{30}$ In the concluding section below, I want to explore the coverage of the departure of the first caravan by one of the Lebanese-Armenian newspapers, Aztarar (Monitor), a weekly newspaper sympathetic to the Armenian nationalist Dashnak party. Its varying representations indicated shifting identifications, signaling their adaptability. 
Aztarar filled its issues with photographs and dedicated their entirety to covering repatriation. ${ }^{31}$ On the day after the first caravan sailed, below the headline "Bon Voyage to the departing, may those remaining soon join [you]!" Aztarar displayed two large photographs above and below each other. ${ }^{32}$ The top one, the transport ship the Transylvania, showed the joyful repatriates wishing Lebanon and their families farewell. ${ }^{33}$ The one below was also of jubilant crowds, but of those gathered at the port wishing the departed well. ${ }^{34}$ Aztarar goes on to describe the actual departure of the first caravan, signaling what it identifies as the beginning of the end to the Armenian diasporic condition ${ }^{35}$ :

At three o'clock, the ship finally sailed. With everyone's eyes filled with tears and their hands waving handkerchiefs, suddenly, and in the midst of shouts of jubilance and cheer, a chorus of song was heard from aboard the ship. It was an over-one-thousand-person choir. The departing--the old, the young, women, men--all of them individually and collectively were singing the anthem of the Lebanese independent republic. Back at the dock, hundreds of people along with many policemen, stood at attention, totally stunned. It is impossible to describe their emotion and their joyous applause that followed. ${ }^{36}$

The national anthem of Lebanon was used to begin the journey to the Armenian homeland. While "impromptu" singing could be interpreted as the repatriates' final act as former Lebanese citizens and performed out of respect for their hosts, I would like to submit an additional reading of the event and its description provided by Aztarar. The entire movement was filled with hybrid national representations: the boat being of German origin, and made Soviet, it being led by a Soviet captain and crew, the name of the ship referring to a central region in Romania. In fact, in order to solve the diasporic condition of Armenians, the homeland was made by non-Armenians. Even in the singing of the Lebanese national anthem when leaving Lebanon, which could be seen as the new nation's first public communiqué, fused representations emerge. Their first public act as new Soviet compatriots who were "reuniting" with their brothers and sisters in the homeland (through the help of their brothers and sisters in the diaspora and the states of Lebanon and the USSR) was to sing an ode to the independent Lebanese republic. This caused an emotional reaction not only from all those on that boat, but also from the Lebanese citizens (Armenian and non-Armenian) who were left at the dock. Was this act of singing the manifestation of combined national identifications that subvert the homogenizing power of the state, even as state powers (the Soviet and the Lebanese) ensure the success of this popular repatriation project?

Aztarar's account of the singing was then followed by an analysis of the scene involving the question "When did they learn this anthem and how?"37 The paper went on to answer "Part of the group knew the anthem already, but the remainder had studied it in Damascus and Beirut." 38 While Aztarar expressed discomfort regarding a display of Lebanese patriotism, which might be seen as an affront to the repatriation narrative, I argue it is precisely a moment of Armenians in Lebanon exhibiting a flexibility of national identifications. And yet, such manifestations have long been ignored within both the earlier histories of Lebanon and more recent contributions that go beyond their initial limitations.

Repatriation coverage in Lebanon represents untapped resources that complicate both traditional and corrective narratives of the history of Lebanon. This article demonstrates how Armenians and non-Armenians, along with the Lebanese and Soviet governments, constructed the homeland of Armenians in Lebanon - forcing a reevaluation of an 
"Armenian" activity. The multi-actors involvement shatters commonly understood constructed categories of their homeland, nation, and national belonging. In considering Armenian inhabitants in Lebanon, only to ascribe them to another space beyond the border, necessitates neglecting compound affiliations and the actions of the Lebanese and Soviet governments in shaping each other's national membership. These readings, along with ignoring the actions of Armenian inhabitants completely, restrict Lebanese historiography, preventing the field from challenging the overused framework of Lebanon's abnormality. A critical reconceptualization of such events as the repatriation narrative changes - and challenges - how we study Armenians, Armenians in Lebanon, and Lebanese.

\section{Acknowledgement}

The author thanks Elizabeth Johnston, Linda Sayed, Paul Sedra, and the anonymous reviewers for helpful comments and suggestions on an earlier draft of this article.

\section{Short Biography}

Tsolin Nalbantian is an Assistant Professor of Contemporary Middle East History at Leiden University in the Netherlands. She is a historian who focuses on state and society in Syria and Lebanon in the 20th century. Her research interests include examining the roles minorities have played in the construction of both the nation-state and nationalism; the interactions of diasporic populations with other populations and the state in the Middle East; and the politicization of identity. She is currently working on a book entitled Fashioning Armenians in Lebanon, 1943-1960.

\section{Notes}

* Correspondence: Middle Eastern Studies, Leiden University, 2300 RA Leiden, the Netherlands. Email: t.nalbantian@hum. leidenuniv.nl.

1 L. Abu Lughod. "Zones of Theory in the Anthropology of the Arab World," 267-306.

2 See for example: Fisk, Pity the Nation; El-Solh, Lebanon and Arabism; Firro, Metamorphosis of the Nation; Harris, Faces of Lebanon; Hanf, Coexistence in Wartime Lebanon; Hirst, Beware of Small States; Khalef, Civil and Uncivil Violence in Lebanon; McDowall, Lebanon, A Conflict of Minorities; Piccard, Lebanon, a Shattered; Salibi, Crossroads to Civil War; Shehadi et al. Lebanon: A History of Conflict and Consensus.

${ }^{3}$ Scholars of Lebanon identify an unstable status quo, attempts to retrace the violent predicament of Lebanon, and then contribute to the rising tension by narrating a sequence of violent events - one more vicious than the other. The climax centers around the larger Civil War of 1975 that lasted until 1991 and ends with a non-resolution of the Ta if Agreement that resulted in the lasting abatement of hostilities. Nevertheless, the reader is made aware of additional tensions that continue to fester, reinforcing that instability is inherent and permanent to Lebanon.

4 By emphasizing that it was the French (and therefore the colonial power) who allowed this outside population to settle in Lebanon (especially by extending citizenship to Armenians in 1924 as a consequence of the Treaty of Lausanne and as a way to increase its Christian population), historians also therefore defend Lebanese nationalist imaginations of both the formation and composition of Lebanon.

5 I use the term "identification" rather than identity as argued by Rogers Brubaker and Fredrick Cooper (2000) as identification forces the specification of the agents doing the identifying, allowing for the consideration of agency. In addition, Brubaker (2005 and 2009), Chen (2004), Chow (1993), Goldschmidt (2000), Safran (1991), Tambiah (2000), and Tölölyan (1996, 2000, 2007, and 2004) have been instrumental in considering additional ways of understanding traditionally categorized diasporic communities, including the Jewish, Greek, and Armenian populations. Ong (1999) has aided in my conceptualization of transnationalism and transnational identification.

${ }^{6}$ Despite his protestations to the contrary, Salibi's text both reads and is cited as a paradigmatic history of Lebanon. Salibi, A House, 1-3; 163-164. There are additional works here that could have been included here including Choueiri (1994), Fawaz (1991) Hitti (2007).

7 Salibi, $A$ House, 4, 46, 82, 137, 147. 
8 Salibi, $A$ House, 4.

9 Traboulsi, A History of Modern Lebanon.

10 Traboulsi, A History of Modern Lebanon, vii.

11 For works that stress the pre-Islamic, Phoenician origins of Lebanese history, al-Sawda, Tarikh Lubnan; and Bulus, Tarikh Lubnan. For works that emphasize the Islamic movement and its influence on Lebanese histories in order to buttress pan-Arabism, see al-Dinnawi, Qira'ah islamiyyah; Bayhum, Lubnan Bayna Musharriq wa Mugharrib; and Hallaq, Lubnan Min al-Finiqiyah.

12 See for example, Abu Zayd, al-Mawarinah; Al-Dibs, Al-Jami' al-mufassal; and Daw, Tarikh al-mawarinah.

13 A. Abu 'Izz al-Din, al-Hawadith, 73 and Taqī al-Dīn, al-Mas'alah.

14 In addition to Abu 'Izz al-Din and Taqi al-Din, see for example, Antonius, The Arab Awakening; Hitti, History of Syria. Neither consider the Armenian population in the construction of national identities in the region. Also, while both of these works are written in English, they heavily rely on Arabic sources.

15 Hojairi, "Church Historians and Maronite Communal Consciousness".

16 I am specifically referring to the following works: Chalabi, Shi' is of Jabal 'Amil; Y. Hazran, "Between Authenticity and Alienation: The Druzes and Lebanon's History", 459-487; and Weiss, In the Shadow of Sectarianism. In addition to these newer works, Ahmad Beydoun's Identité Confessionnelle et Temps Social Chez les Historiens Libanaises Contemporains and 'A Note on Confessionalism' emphasize the importance of the Shi'i community in constructing the Lebanese narrative.

17 The origins of the Shi'a were questioned as the Lebanese nation-state was formed. During the French Mandate, Lebanese Shi'i were accused of being outsiders due to an alleged "Persian" ancestry. Still, by the time of independence in 1946, the Shi'i were considered - albeit an insignificant - Lebanese population. Linda Sayed addresses the allegation of Persian ancestry during the formative period of creating Lebanese Shi'i citizens during the French mandate. Still, while critically challenging the "Persian" status, such readings do so to demonstrate their native belonging. I am interested in examining belonging in the context of a non-native paradigm. Sayed "Becoming Modern".

18 Again, I believe it is important to restate that I am not accusing Lebanese historiography of reinforcing nation-state nationalism because of an absence of Armenian histories. Instead, I am interested in exposing how the narratives of the Lebanese nation-state are reinforced by histories of marginal groups, such as the Shi'i and Druze. In so doing, I explore how the Armenian absence in Lebanese histories prevents us from fully engaging how concepts and constructions of citizenship and identification were understood in this very formative period in Lebanese history.

19 I have chosen to examine Hovannisian's and Panossian's works as their approaches best match the methods employed by Salibi and Traboulsi. There are additional works that could have been included here that maintain a "grand narrative" such as Paysalian (2007) and Suny (1993). The works of Messerlian (1963) and Schahgaldian (1979 and 1983), Tyutunjyan (1992), and Varzhapetean 1982) all study Armenian political engagement in Lebanon. Still, they view Armenians specifically as a minority community connected to an external homeland. There are two works, however, Migliorino, (Re)Constructing Armenia and Boudjikanian (ed), Armenians in Lebanon, which focus on the Armenian population of Lebanon. Still, they continue to reinforce the problems I maintain in the body of this essay. While Migliorino's work does offer fresh insight into the arrival of the Armenian population in Syria and Lebanon, and traces their growing involvement in both the Lebanese and Syrian political and institutional systems, it does so through the specific approach of the Armenian population as a minority group. This positioning limits the understanding of Armenian engagement in Lebanon as one that responds only to (a more authentic) majority. Armenians of Lebanon, a collection of essays on the history of the Armenian community in Lebanon, uses a similar approach of separatism. Armenians are first identified as a distinct community, originating from outside of Lebanon. The history that follows therefore is happening in Lebanon, but is not necessarily part of Lebanese history. Other works that attempt to sever Armenians from their "minority" or "diasporic" status include Der Matossian (2008). Nevertheless this work is limited to the Ottoman Empire and the Second Consitutional Period.

20 Hovannisian, "Introduction", vii.

21 Panossian, The Armenians, vii.

22 Panossian, The Armenians, vii.

23 Panossian, The Armenians, 292. (Original emphasis.)

24 The Council of People's Commissars was the highest government authority in the Soviet Union until 1946 when it was replaced by the Council of Ministers of the USSR. "Nergaght'ě", Nor Oughi (Beirut), 5(9) 1946, 231.

25 All Armenian press outlets worldwide, regardless of political persuasion and religious denomination, avidly welcomed and celebrated the endeavor.

26 The Armenian repatriation movement was not the only organized mass population transfer between nation-states taking place during this period. The Zionist project in Palestine and the movement to partition India into two states, India and Pakistan, were gaining in popularity and momentum. Like other "repatriations," the Armenian worldwide population did not, and could not, trace its roots - whether real or imaginary - to the Soviet Republic of Armenia.

27 These passengers - until the moment they stepped upon the ship - were either Lebanese or Syrian citizens, and had been so since the French mandate powers had extended citizenship to Armenian refugees in 1924. This extension was 
thereafter guaranteed by the independent states of Syria and Lebanon. The great majority of the Armenian population of Syria and Lebanon had arrived as refugees from the Ottoman Empire, areas that had become part of the Republic of Turkey since 1923. I maintain that the success of this movement would be peculiar even if the 100,000 returnees could trace their roots to the geographic areas of Soviet Armenia. Nevertheless, why I categorize the movement here to be peculiar is because it was engineered as a repatriation or return and was successful as such - even though no one involved in the process would have been able to justify the movement of thousands as a "return."

28 'Nergaght ě', Nor Oughi, 231.

${ }^{29}$ I use the word de-naturalization purposefully, as it suggests that this process was not natural. It wasn't. It was due to the engineering of nation-states, such as the USSR and Lebanon, which, because of their approval of this population transfer, pushed for the resolution of the Armenian diasporic condition.

${ }^{30}$ In the first year of repatriation (1946), none of the Armenian press outlets in Lebanon spoke against the movement. While it is true that Aztag (Power/Factor), the daily associated with the nationalist Dashnak party did engage in disputes with rival party newspapers at the time, including Ararad and Zartonk, none of the outlets specifically engaged with the ideology of repatriation. Rather, these clashes centered around contesting the reported statements made by resigning members of the Dashnak political party and its affiliated organizations (which was a requirement demanded by Soviet authorities to all those repatriating). This situation changed relatively quickly in that by 1947 , Dashnak party affiliated newspapers, especially Aztag, did not dedicate as much space to the events surrounding repatriation. Still, all outlets continued to at least follow the population transfer, and it was not until the movement neared its end, in 1949, that Aztag became heavily critical. In addition, it should be noted that other newspapers sympathetic to the Dashnak party, such as Aztarar continued to follow repatriation with relatively consistent interest. By the early 1950s however, most - if not all - of the Dashnak associated newspapers avidly spoke against the movement, the Soviet State of Armenia, the USSR, Zartonk, Ararad, and its associated parties. Most contemporary Armenian historiographies, including Migliorino, (Re)Constructing Armenia, do not detail these changes, maintaining that the Dashnak party was always against repatriation.

31 All Armenian newspapers in Lebanon, to varying degrees, supported the repatriation movement, some more ambivalent than others. Without explicitly labeling Soviet Armenia as the homeland of the Armenians, Aztag, the Armenian daily of the Armenian nationalist Dashnak party, still identified the place that these travelers were moving to as the homeland. It also tacitly supported the process by connecting the emotion at separating from their families and history in Lebanon to the imagined exhilaration felt at reuniting with the homeland. See for example, 'Nergaght'i Arajin Karawaně', Aztag (Beirut), 25 June 1946, sec 1: 1. In their offers of well wishes, however, it is unclear if $A z$ tag identified those leaving as "compatriots" with those who remain. Are these repatriates compatriots because they share the same "tears-worth of memories" in Lebanon as Lebanese, or as Armenians, or both? If Armenians in Lebanon identified themselves as Lebanese and Armenian, could that challenge the Soviet state's construction of the Armenian homeland in the USSR and the "reunification" of the Armenian diaspora supported by the Lebanese state, and its Arabic and Armenian press?

32 'Bari Chanaparh Hayrenik' Meknoghnerun', Aztarar (Beirut), 29 June 1946, sec 1: 1.

33 This is in marked contrast to Aztag, the daily of the Armenian nationalist Dashnak party, which did not call for all Armenians in Lebanon to repatriate and which mentioned the pain of separation alongside the joy of return. In fact, in the same week that Aztarar ran this headline, Aztag ran a declaration on its front page by the highest figure of the Armenian church in Lebanon that stated "It is the natural duty of the Armenians of the Diaspora to help their brothers and sisters, no matter how minor the assistance, to defray the enormous costs of repatriation proportionally." (Vehap'ar'in Koch'ě' Aztag (Beirut), 26 June $1946 \mathrm{sec}$ 1: 1.) This declaration encouraged Armenians in Lebanon to support repatriation without repatriating themselves. While this is a pragmatic response to the popularity of the project, all Armenians did not define themselves as belonging to the USSR, opting to remain in Lebanon. This remaining population secured the place of Armenians within Lebanese history, and yet is not present in its historiography. After all, the Armenians who stayed behind reinforced their status as Lebanese citizens as they were given the opportunity by both governments to "repatriate" and chose not to.

34 'Bari Chanaparh', Aztarar, 1.

35 'Bari Chanaparh', Aztarar, 1.

36 'Bari Chanaparh', Aztarar, 1.

37 'Bari Chanaparh', Aztarar, 8.

38 'Bari Chanaparh', Aztarar, 8.

\section{Bibliography}

Abu 'Izz al-Din, A., al-Hawadith 1142, (September 1978), 73.

Abu Lughod, L., 'Zones of Theory in the Anthropology of the Arab World', Annual Review of Anthropology, 18 (1989): 267-306.

Abu Zayd, S., al-Mawarinah su'al fi al-hwwiyyah (Beirut: Dar Ab'ad li al-Tiba'ah wa al-Nashr, 2000).

Al-Dibs, Y., Al-Jami' al-mufassal fi tarikh al-mawarinah al-mu'assal (Beirut: Dar Lahd Khater, 1987).

Al-Dinnawi, M. A., Qira'ah islamiyyah fi tarikh lubnan wa al-mintaqah (Beirut: Dar al-'Iman, 1985). 
Antonius, G., The Arab Awakening (Beirut: Librarie Du Liban, 1969).

Bayhum, J., Lubnan Bayna Musharriq wa Mugharrib (Beirut: self published, 1969).

Beydoun, A., Identité Confessionnelle et Temps Social Chez les Historiens Libanaises Contemporains (Beirut: L’Université Libanaise, 1984).

Beydoun, A., 'A Note on Confessionalism', in T. Hanf and N. Salam (eds.), Lebanon in Limbo (Baden-Baden, Baden: Nomos Verlagsgesellschaft, 2003), 75-86.

Brubaker, R., 'The 'Diaspora' Diaspora', Ethnic and Racial Studies, 28/1 (2005): 1-19.

Brubaker, R. 'Ethnicity, Race, and Nationalism', Annual Review of Sociology, 35 (2009): 21-42.

Brubaker, R., and Cooper, F., 'Beyond Identity', Theory and Society, 29/1 (2000): 1-47.

Bulus, J., Tarikh Lubnan (Beirut: Dar al-Nahar, 1972).

Chalabi, T., Shi'is of Jabal 'Amil and the New Lebanon: Community and Nation State, 1918-1943 (New York: Palgrave Macmillan, 2006).

Chen, Z., "Building the Chinese Diaspora across Canada: Chinese Diasporic Discourse and the Case of Peterborough, Ontario', Diaspora, 13/2-3 (2004): 185-210.

Choueiri, Y. M., (ed.), State and Society in Syria and Lebanon (New York: St. Martin's Press, 1994).

Chow, R., Writing Diaspora: Tactics of Intervention in Contemporary Cultural Studies (Bloomington: Indian University Press, 1993).

Daw, B., Tarikh al-mawarinah al-dini wa al-siyyasi wa al-hadari. (Beirut: Dar al-Nahar, 1972).

Der Matossian, B., 'Ethnic Politics in Post-Revolutionary Ottoman Empire: Armenians, Arabs, and Jews in the Second Constitutional Period (1908-1909)', Ph.D. diss. (Columbia University, 2008).

El-Solh, R., Lebanon and Arabism (London: I.B. Tauris, 1998).

Fawaz, Leila, (ed.), State and Society in Lebanon (Oxford: Oxonian Rewley Press Ltd, 1991).

Firro, K., Metamorphosis of the Nation (al-Umma):The Rise of Arabism and Minorities in Syria and Lebanon, 1850-1940 (Portland, OR: Sussex Academic Press, 2009).

Fisk, R., Pity the Nation: The Abduction of Lebanon (New York: Simon Schuster, 1990).

Goldschmidt, H., 'Crown Heights is the Center of the 'World': Reterritorializing a Jewish Diaspora', Diaspora, 9/1 (2000): 83-106.

Hallaq, H., Lubnan Min al-Finiqiyah ila al-'Urubah (Beirut: al-Dar al-Jami'yyah, 1993).

Hanf, T., Coexistence in Wartime Lebanon: Decline of a State and Rise of a Nation (London: IB Tauris, 1993).

Harris, W., Faces of Lebanon: Sects, Wars, and Global Extensions (Princeton, NJ: Markus Wiener Publishers, 1997).

Hazran, Y., 'Between Authenticity and Alienation: The Druzes and Lebanon's History', Bulletin of the School of Oriental and African Studies, 72/3 (2009): 459-487.

Hirst, D., Beware of Small States: Lebanon, Battleground of the Middle East (New York: Nation Book, 2010).

Hitti, P., History of Syria, Including Lebanon and Palestine (London: Macmillan, 1951).

Hitti, P. The Origins of the Druze People and Religion (London: Saqi, 2007).

Hojairi, M. M., 'Church Historians and Maronite Communal Consciousness: Agency and Creativity in Writing the History of Mount Lebanon', Ph.D. diss. (Columbia University, 2011).

Hovannisian, R. G., (ed.), The Armenian People from Ancient to Modern Times (New York: St. Martin's Press, 1997).

Khalef, S., Civil and Uncivil Violence in Lebanon: A History of the Internationalization of Communal Conflict (New York: Columbia University Press, 2002).

McDowall, D., Lebanon, a Conflict of Minorities (London: Minority Rights Group, 1996).

Messerlian, Z. M., 'Armenian Representation in the Lebanese Parliament', M.A. Thesis (American University in Beirut, 1963).

Migliorino, N., (Re)Constructing Armenia in Lebanon and Syria Ethno-Cultural Diversity and the State in the Aftermath of a Refugee Crisis (New York: Berghahn Books Inc., 2007).

Ong, A., Flexible Citizenship: The Cultural Logics of Transnationality (Durham: Duke University Press, 1999).

Panossian, R., The Armenians: From Kings and Priests to Merchants and Commissars (New York: Columbia University Press, 2006).

Paysalian, S., History of Armenia: From the Origins to the Present (New York: Palgrave Macmillan, 2007).

Piccard, E., Lebanon, a Shattered Country: Myths and Realities of the Wars in Lebanon (New York: Holmes and Meier, 1996).

Safran, W., 'Diasporas in Modern Societies: Myths of Homeland and Return', Diaspora, 1 (1991): 83-99.

Salibi, K., Crossroads to Civil War: Lebanon 1958-1976 (Delmar, NY: Caravan Books, 1976).

Salibi, K. A House of Many Mansions: The History of Lebanon Reconsidered (London: I.B. Tauris, 1988).

al-Sawda, Y., Tarikh Lubnan al-Hadari (Beirut: Dar al-Nahar, 1972).

Sayed, L., 'Becoming Modern Lebanese Shi'i Citizens under the French Mandate 1918-1943', Framing Minority Community

Identities: Comparative Notes from India and Lebanon Panel, AHA Convention (Chicago, Ill., 5 January 2012).

Schahgaldian, N., 'The Political Integration of an Immigrant Community into a Composite Society: The Armenians in Lebanon, 1920-1974'. Ph.D. diss. (Columbia University, 1979).

Schahgaldian, N., 'Ethnicity and Political Development in the Lebanese-Armenian Community, 1925-1975', Armenian

Review, 36/1/141 (Spring 1983), 46-61.

Shehadi, N., and Mills, D. H., (eds.), Lebanon: A History of Conflict and Consensus (I.B. Tauris Co Ltd, 1988).

Suny, R., (ed.), Looking Towards Ararat. Armenian in Modern History (Bloomington: Indiana University Press, 1993). 


\section{Beyond Overlooked Populations in Lebanese Historiography}

Tambiah, S., 'Transnational Movements, Diaspora, and Multiple Modernities', Daedalus, 129/1 (2000): $163-194$.

Taqī al-Dīn, S., al-Mas'alah al-ta'ifìyah fì Lubnān: al-judhūr wa-al-tatawwur al-tārīkhī (1985).

Tölölyan, K. 'Rethinking Diaspora(s): Stateless Power in the Transnational Moment', Diaspora, 5/1 (1996): 3-36.

Tölölyan, K. 'Elites and Institutions in the Armenian Transition', Diaspora, 9/1 (2000): 107-136.

Tölölyan, K., 'The Contemporary Discourse of Diaspora Studies', Comparative Studies of South Asia Asia, Africa, and the Middle East, $27 / 3$ (2007): 641-655.

Tölölyan, K., Kokot, W., and Alfonso, C., (eds.), Diaspora, Identity, and Religion: New Directions in Theory and Research (London/New York: Routledge, 2004).

Traboulsi, F., A History of Modern Lebanon (London: Pluto Press, 2007).

Tyutunjyan, P., Libanani zhoghovrdi azatagrakan payk'are ev hay hamaynk'e (1920-1990) (Yerevan: Luys, 1992).

Varzhapetean, S. H., Hayere Libanani mej: hanragitaran libananahay gaghut'i, 5 vols. (Beirut: Vahe Setian Printing Press, 1982).

Weiss, M., In the Shadow of Sectarianism: Law, Shi'ism, and the Making of Modern Lebanon (Cambridge: Harvard University Press, 2010). 